\title{
A BLOKK-DIAGRAM ÉS A HIBAFA ELEMZÉS KAPCSOLATA
}

\section{THE RELATION OF BLOCK-DIAGRAM AND FAILURE TREE ANALYSIS}

\author{
Farkas Levente $^{1}$, Pokorádi László ${ }^{2}$ \\ I'Óbudai Egyetem, Bánki Donát Gépész és Biztonságtechnikai Mérnöki Kar, \\ Magyarország 1081 Budapest, Népszínház u. 8, leventefarkas@freemail.hu \\ ${ }^{2}$ Óbudai Egyetem, Bánki Donát Gépész és Biztonságtechnikai Mérnöki Kar, \\ Magyarország1081 Budapest, Népszínház u. 8, pokoradi.laszlo@bgk.uni-obuda.hu
}

\begin{abstract}
One of the most important tasks of the technical safety science is the reliability investigation of used systems and technological processes. Lot of reliability and risk assessment methods, procedures is known. The two most commonly used are the Block Diagram, and the Failure Tree Analysis. Authors of this paper show these two procedures mentioned above, as well as demonstrate the relationship between them by a simply case study.
\end{abstract}

Keywords: reliability, failure tree analysis, block-diagram.

\section{Összefoglalás}

Az egyik legfontosabb müszaki biztonságtudományi feladat az üzemeltetett rendszerek, technológiai folyamatok megbízhatósági vizsgálatai. Több megbízhatósági és kockázatelemző módszer, eljárás ismert. Ezek közül a két leginkább használt a blokk-diagram, valamint a hibafa elemzés. A dolgozatban a Szerzők egy rövid példán bemutatják a fent említett két eljárást, valamint feltárják a köztük lévő kapcsolatot.

Kulcsszavak: megbizhatóság, hibafa elemzés, blokk-diagram.

\section{Bevezetés}

A müszaki gyakorlatban rendkívül jelentős szerepet játszanak a rendszerek megbízhatósági vizsgálatai [1]. Egy helyesen megalkotott elemző modell segítségével gyakran előre kiszürhetők az üzemeltetés során fellépő müszaki hibák. A megbízhatósági elemzés célja, hogy ezeket a modelleket vizsgálva megállapítsuk egy rendszer vagy folyamat várható élettartamát, illetve meghibásodási valószínüségét.

A kanonikus rendszerek lényegi tulajdonsága az, hogy az egyes elemek vizsgálatakor „csak” két üzemállapotot különböztetünk meg: üzemképes, vagy üzemképtelen.
Dolgozatunkban nem vizsgáljuk külön a lehetséges meghibásodások módját. Nem elemezzük azt például, hogy egy hálózatba kapcsolt számítógép (amit így elemként kezelünk) a processzora vagy a tápegysége miatt hibásodott meg.

Tanulmányunk célja a blokk-diagram, illetve a hibafa elemzések bemutatása és a köztük lévő kapcsolatok feltárása, szemléltetése.

A Boole változókkal felírt kanonikus struktúrákat blokk-diagramnak nevezzük, amelyre a 2. fejezetben fogunk visszatérni. A 3. fejezetben a hibafa-elemzést mutatjuk be. A két módszert egy tanpéldával illusztráljuk. Végül összegezzük munkánk ered- 
ményeit.

Az elemzésre kerülő rendszer megbízhatósági blokk-diagramját az 1. ábra szemlélteti.

\section{A blokk-diagram elemzés}

A blokk-diagram egy olyan grafikus megbízhatósági elemző módszer, amely a rendszerben szereplö elemeket funkciójuk szerint ábrázolja. Az elemek kapcsolata tükrözi a müködési kapcsolatot. A megbízhatósági blokk-diagram az elemeknek a rendszer müködőképességére gyakorolt hatását mutatja be, és az egyes elemek megbízhatóságából határozható meg a rendszer megbízhatósága. A blokk-diagram elemei alapvetően kétféleképpen kapcsolódhatnak egymáshoz: sorosan, illetve párhuzamosan.

Soros kapcsolású rendszer esetén bármelyik elem meghibásodása a rendszer üzemképtelenségét okozza [3]. Ilyen kapcsolatra látunk példát a rendszer $\boldsymbol{Q}$ és $\boldsymbol{R}$ elemei esetén.

Párhuzamosnak nevezzük azt a rendszert, amelyik mindaddig üzemképes, amíg egyetlen eleme is még müködőképes. Ez a kapcsolat biztonságosabb, hiszen elemei redundánsak. Ez a kapcsolat jelenik meg a rendszer $\boldsymbol{Y}$ és $\boldsymbol{Z}$ elemei között.

Fontos hangsúlyozni, hogy a megbízhatóság szempontjából vizsgált modellekben a soros és párhuzamos kapcsolat nem azonos az elemek valóságban elfoglalt helyzetével!

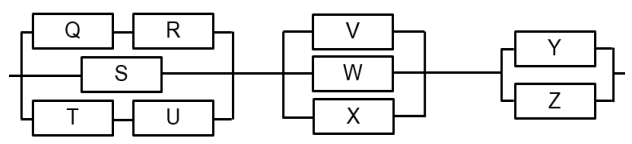

1. ábra $A$ rendszer blokk-diagramja

Az 1. ábrán bemutatott rendszer elemzése során első lépésként a legalsó szintü elemcsoportokat vizsgáljuk (2. ábra). Az elemeket rétegenként csoportosítjuk, és sorszámozzuk. Így kapunk a $\boldsymbol{Q}$ és $\boldsymbol{R}$ ele- mekből 11-es blokkot, a $\boldsymbol{T}$ és $\boldsymbol{U}$ elemekből 12-es blokkot. Ezt a logikát követjük a későbbiekben is.
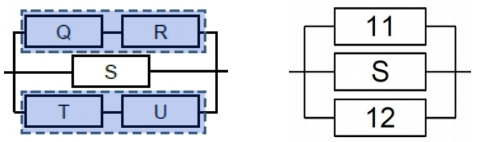

2. ábra $A$ 11. és 12. blokkok diagramja

Az úgy kapott új blokkok megbízhatóságát az egyes elemek megbízhatóságának szorzata adja soros kapcsolat esetén, azaz:

$$
\begin{aligned}
& R_{11}=r_{Q} r_{R} \\
& R_{12}=r_{T} r_{U}
\end{aligned}
$$

A következőkben a rendszer további rétegeiben található részrendszereket vizsgáltam. Második lépésben a 3. ábrán látható rendszer blokkjainak megbízhatóságát számoltuk. A párhuzamos kapcsolat miatt a képlet a következők szerint módosult:

$$
\begin{aligned}
& R_{1}=1-\left\{\left(1-R_{11}\right)\left(1-r_{S}\right)\left(1-R_{12}\right)\right\} \\
& R_{2}=1-\left\{\left(1-r_{V}\right)\left(1-r_{W}\right)\left(1-r_{X}\right)\right\} \\
& R_{3}=1-\left\{\left(1-r_{Y}\right)\left(1-r_{Z}\right)\right\}
\end{aligned}
$$

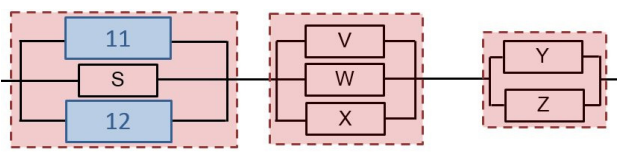

3. ábra $A z$ 1., 2. és 3. blokk diagramjai

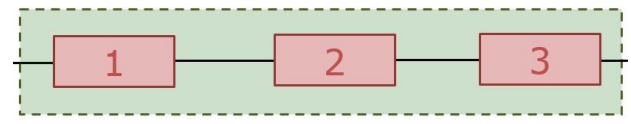

4. ábra $A$ teljes rendszer blokk-diagramja

A teljes rendszer megbízhatósága pedig a következő módon számítható:

$$
R=R_{1} R_{2} R_{3}
$$

Ha mindegyik elem megbízhatósága $r_{i}=0,9$, akkor a vizsgált rendszer megbízhatósága $R=0,985439674$. 


\section{A Hibafa elemzés}

A hibafa elemzés egy olyan rendszerelemző módszer, amit a rendszer hibájának felderítésére alkalmazhatunk [2]. A hibafaelemzés során az elemek és alrendszerek közötti kapcsolat módja legalább olyan fontos, mint maguk az elemek. Ez az egymáshoz való viszony határozza meg az elemzés során használandó müveletek sorrendjét.

A módszer során egy föeseményböl indulunk ki, melyet gyakran az angol elnevezésével (Top Event-tel) jelölünk. Az elemzés során fokozatosan derítjük fel a föesemény meghibásodási lehetőségeit, amelyek részrendszereket alkotnak, és tovább bonthatók, egészen addig, amíg meg nem kapjuk az elemi eseményeket.

$\mathrm{Az}$ elemeket és blokkokat úgynevezett logikai kapukkal kapcsoljuk egymáshoz, és fajtánként eltérő jelöléssel különböztetjük meg öket vizuálisan. Két leggyakoribb logikai kapcsolat az $E S$ kapu, illetve $V A G Y$ kapu.

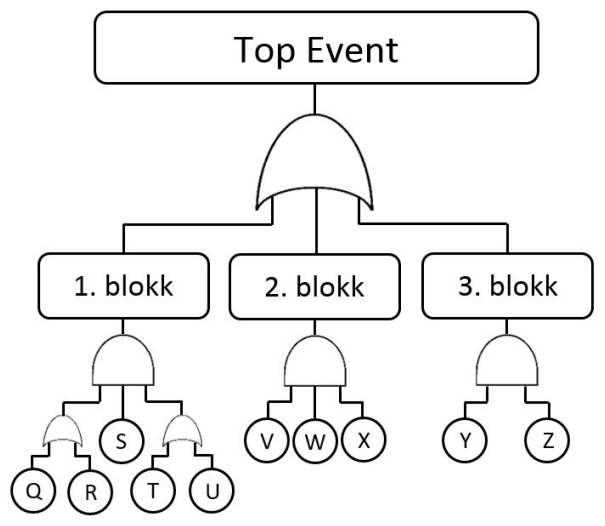

5. ábra $A$ teljes rendszer hibafája

$E ́ S$ kaput akkor alkalmazunk, ha a kimeneti esemény akkor és csak akkor következik be, hogyha az összes bemeneti esemény bekövetkezik.

$V A G Y$ kapuval mutatjuk azt a kapcsolatot, ha a kimeneti esemény azonnal bekövetkezik, amint a bemeneti események kö- zül bármelyik elöáll.

A teljes rendszer müködésképtelenségének valószínüsége a következő egyenlettel számolható:

$$
P=1-\left\{\left(1-P_{1}\right)\left(1-P_{2}\right)\left(1-P_{3}\right)\right\}
$$

A rendszer 3 további blokkra oszlik. Az 1. blokk $E ́ S$ kaput tartalmaz, tehát akkor hibás, ha a 11. blokk $E ́ S$ az $S$ elem $E S$ a 12. blokk is hibás:

$$
P_{1}=P_{11} p_{S} P_{12}
$$

Az $S$ elemen kívül mindkettő blokk tovább bontható. A 11. és 12. blokkok kétkét, egymással ÉS kapuval kapcsolt elemből állnak. Akkor nem müködik a 11. blokk, ha a $\boldsymbol{Q}$ elem $E S$ az $\boldsymbol{R}$ elem is hibás, illetve a $\mathbf{1 2}$. blokk, ha a $\boldsymbol{T}$ elem $E ́ S$ az $\boldsymbol{U}$ elem is hibás:

$$
\begin{gathered}
P_{11}=1-\left\{\left(1-r_{Q}\right)\left(1-r_{R}\right)\right\} \\
P_{12}=1-\left\{\left(1-r_{T}\right)\left(1-r_{U}\right)\right\}
\end{gathered}
$$

A 2. blokk ÉS kaput tartalmaz, tehát akkor hibás, ha a $\boldsymbol{V}$ elem $E S$ az $\boldsymbol{W}$ elem $E S$ a $\boldsymbol{X}$ elem is hibás:

$$
P_{2}=p_{V} p_{W} p_{X}
$$

A 3. blokk is $E S$ kaput tartalmaz, azaz akkor hibás, ha az $\boldsymbol{Y}$ elem $E ́ S$ az $\boldsymbol{Z}$ elem hibás:

$$
P_{3}=p_{Y} p_{Z}
$$

Minden elemnél a $p_{i}=0,1$ meghibásodási valószínüséggel (ami megfelel az előző fejezetben példaként használt $r_{i}=0,9$ esetnek) számolva a teljes rendszer müködésképtelen állapotának valószínüsége: $P=0,014560326$.

\section{Következtetések}

Jelen cikkben egy egyszerü példán keresztül bemutattuk a két legelterjedtebb megbízhatósági elemzési eljárást. Ezen módszerek a mérnöki gyakorlatban kiemelt fontossággal bírnak, hiszen segítségükkel 
modellezhetők le a különböző rendszerek, gyártósorok, berendezések várható meghibásodása, élettartama, és így már azelőtt megtörténhet a beavatkozás, hogy a leállás bekövetkezne.

A fenti két megbízhatósági elemzés elsőre különbözőnek tünhet, azonban gyakran átírhatók egymásba, és kölcsönösen kiegészítik egymást.

A 1. ábrán bemutatott rendszer teljes egészében megfeleltethetô az 5. ábrán bemutatott hibafának. A fóesemény, azaz a Top Event azt az állapotot mutatja, amikor a rendszer müködésképtelen. A hibafa elemzésnél használt logikai kapuk a megfelelő párjai a blokk-diagram kapcsolatoknak: A hibafán a sorba kapcsolt 1, 2. és 3. blokkok közti megbízhatósági kapcsolatot itt a $V A G Y$ kapu jelképezi. A párhuzamos kapcsolású $\boldsymbol{Y}$ és $\boldsymbol{Z}$ elemek között $E ́ S$ kaput kell használni.

1. táblázat. $A z$ eredmények összehasonlitása különbözö kiindulási értékek esetén

\begin{tabular}{|c|c||c|c|}
\hline \multicolumn{2}{|c||}{ Megbízhatóság } & \multicolumn{2}{c|}{ Meghibásodás } \\
\hline$r_{i}$ & $R$ & $p_{i}$ & $P$ \\
\hline 0,95 & 0,996901 & 0,05 & 0,003089 \\
\hline 0,9 & 0,985440 & 0,1 & 0,014560 \\
\hline 0,85 & 0,962948 & 0,15 & 0,037052 \\
\hline 0,8 & 0,927636 & 0,2 & 0,072364 \\
\hline 0,5 & 0,471680 & 0,5 & 0,528320 \\
\hline
\end{tabular}

Végül egy összehasonlító táblázattal támasztjuk alá a fenti megállapítást, amely bizonyítja, hogy a megbízhatósági tényező és a meghibásodási valószínűség egymást remekül kiegészítik. Az 1. táblázatban különböző tetszőlegesen választott értékeket adtunk meg a rendszer elemeinek, majd ezekkel elvégeztük a számításokat a fent bemutatott egyenletek szerint. Az eredmények jól mutatják, hogy a kapott értékek egymást mindig úgy egészítik ki, hogy: $R+$ $P=1$. Ez gyakorlatilag a vizsgált rendszer kanonikus tulajdonságából adódik.

A cikkben felhasznált rendszer egy kiragadott részlete az [1] forrásban hivatkozott TDK dolgozatnak, melynek célja, hogy részletesen bemutassa a blokk-diagram módszer és hibafa elemzés kapcsolatát.

\section{Szakirodalmi hivatkozások}

[1] Farkas Levente: Kanonikus struktúrák megbizhatósági elemzése, Tudományos Diákköri Dolgozat, Budapest, 2015. (konzulens: Pokorádi László)

[2] Pokorádi László: Hibafa érzékenységelemzése, A XX. Fiatal Müszaki Tudományos Ülésszak Előadásai, Kolozsvár, 2015., pp. 263-266.

[3] Pokorádi László: Komplex kapcsolatú rendszerek megbizhatóságának moduláris érzékenységelemzése, Repüléstudományi Közlemények, XXVII.(1), 2015., pp. 81-89.

\section{Köszönetnyilvánítás}

Tanulmányunk az Óbudai Egyetem Bánki Donát Gépész és Biztonságtechnikai Mérnöki Kar Müszaki Biztonságtudományi Szakmühely $-\mu \beta \sigma-$ keretében készült el.

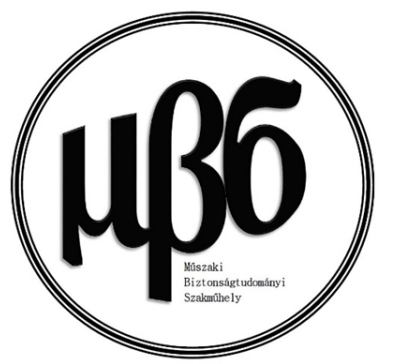

